\title{
Analisis kebutuhan pengembangan buku suplemen sistem pernapasan manusia berbasis teknologi augmented reality sebagai bahan ajar siswa SMP kelas VIII
}

\author{
Aan Setya Nugroho, Munzil*, Erti Hamimi \\ Universitas Negeri Malang, Jl. Semarang No. 5 Malang, Jawa Timur, Indonesia \\ *Penulis korespondensi, Surel: munzil.fmipa@um.ac.id
}

Paper received: 01-02-2021; revised: 15-02-2021; accepted: 28-02-2021

\begin{abstract}
Abstrak
Pengembangan buku suplemen sistem pernapasan manusia berbasis teknologi augmented reality bertujuan untuk menghasilkan sebuah produk bahan ajar IPA SMP kelas VIII yang dapat menarik minat belajar peserta didik dalam menambah pengetahuan yang sesuai dengan tuntutan Kurikulum 2013 yaitu memfasilitasi kegiatan proses pembelajaran siswa pada materi sistem pernapasan manusia. Buku suplemen yang dikembangkan menyediakan sumber belajar berbasis teknologi representatif dengan memanfaatkan peran dari teknologi augmented reality. Peran teknologi tersebut dalam bahan ajar ini yaitu dapat mentransformasikan sebuah objek dalam buku suplemen menjadi lebih nyata dalam bentuk tiga dimensi secara real time. Dengan penggunaan teknologi tersebut memungkinkan dapat membantu siswa dalam memahami konsep-konsep abstrak dalam materi sistem pernapasan manusia menjadi konkrit dan proses pembelajaran berlangsung tidak terbatas ruang dan waktu. Dengan adanya produk ini diharapkan dapat mamfasilitasi peserta didik dalam mengkonstruk pengetahuannya dan menyatupadukannya menjadi sebuah konsep yang utuh dan terpadu. Penelitian dan pengembangan ini bersifat diskriprif dan menggunakan metode penelitian studi lapangan di sekolah terkait pembelajaran IPA mengenai sistem pernapasan manusia.
\end{abstract}

Kata kunci: Pengembangan bahan ajar; Buku suplemen; augmented reality

\section{Pendahuluan}

Ilmu Pengetahuan Alam erat kaitannya dengan proses siswa mempelajari tentang alam dan bukan hanya mengenai penguasaan kumpulan dari berbagai konsep, fakta, maupun prinsip saja (Kurniasih \& Sani, 2014). IPA sebagai komponen dari kurikulum yang mendefinisikan sebagai mata pelajaran yang berupa pengetahuan terpadu dan tersusun secara sistematis terdiri dari sekumpulan data observasi dan eksperimen. Mata pelajaran IPA dikembangkan sebagai mata pelajaran yang cakupannya luas, berorientasi aplikatif, pengembangan keterampilan berpikir, kemampuan belajar, rasa ingin tahu, sikap peduli dan tanggung jawab terhadap lingkungan alam (Anjarsari, 2013). Pembelajaran terpadu menyajikan mengenai pengaplikasian pada dunia nyata yang dialami dalam dalam kehidupan sehari-hari, sehingga dapat mempermudah pemahaman konsep serta memperbaiki dan meningkatkan motivasi belajar siswa (Depdiknas, 2009). Pembelajaran terpadu mempunyai fungsi sebagai tempat penyatupaduan suatu konsep yang terdapat pada suatu pokok bahasan dari beberapa kajian ilmu yang saling berkaitan dan terpadu pemahamannya

Untuk mencapai tujuan pembelajaran sesuai dengan tuntutan kurikulum, maka seorang pendidik mempunyai keharusan dalam melibatkan peran media maupun bahan ajar yang bervariasi dalam proses pembelajaran sebagai wujud penyatupaduan materi dari berbagai ilmu kajian. Faktanya pengadaan bahan ajar maupun media kini semakin kurang inovatif dalam membuat terobosan kegiatan pembelajaran yang menarik. Putu Sukerni dalam Jurnal Pendidikan Indonesia (2014) mengemukakan permasalahan yang terjadi di sekolah 
terkait sumber belajar adalah materi yang terdapat dalam bahan ajar kurang sesuai dengan karakteristik dan kebutuhan siswa, strategi pengorganisasian penyampaian materi dalam bahan ajar kurang teratur dengan baik dan tampilannya yang kurang menarik minat belajar peserta didik. Sejalan dengan tuntutan era global yang bertumpu pada kemampuan profesional, maka konsekuensinya diterbitkan Peraturan Pemerintah nomor 19 tahun 2005 Pasal 20, bahwa guru diharapkan mampu mengembangkan materi pembelajaran sebagai salah satu sumber belajar pada bahan ajar.

Kondisi seperti ini memicu untuk melakukan terobosan dalam menjawab tuntutan era global sesuai dengan kurikulum 2013 yaitu melakukan pengembangan bahan ajar yang disesuaikan dengan karakteristik siswa dan didesain semenarik mungkin dengan melibatkan berbagai komponen pendukung yang relevan dengan isi materi. Komponen tersebut dapat berupa gambar yang divisualisasikan dalam bentuk realistis dengan kombinasi warna yang menarik (Daryanto, 2010). Begitupun untuk materi yang bersifat abstrak dapat dijelaskan dengan mudah dan sederhana melalui media gambar yang relevan.

Gambaran permasalahan tersebut menunjukan perlu adanya perbaikan guna untuk meningkatkan kemampuan dalam menyelesaikan permasalahan pada setiap materi yang akan disampaikan. Usaha tersebut dapat diawali dengan penggunaan bahan ajar pendukung sebagai pelengkap dari buku utama untuk memudahkan pemahaman konsep siswa, sehingga dapat tercapainya tujuan pembelajaran secara maksimal (Arifudin, 2011). Berdasarkan penelitian yang telah dilakukan oleh Kumalasari $(2014,463)$ mengemukakan bahwa sangat diperlukan suatu inovasi dalam kegiatan pembelajaran pembelajaran dengan menerapkan media pembelajaran yang bahan ajarnya mudah dipahami dengan penggunaan kata-kata yang sederhana tetapi tidak mengesampingkan makna dari kata sesungguhnya. Buku ini sangat dibutuhkan dalam pembelajaran karena dapat menambah kreativitas, meningkatkan penguasaan iptek serta pengetahuan siswa. Berdasarkan pemaparan diatas, buku suplemen sebagai buku penunjang dari buku teks utama perlu dikembangkan dan dikaji kembali guna mengatasi masalah pembelajaran yang cenderung membosankan dengan hanya memanfaatkan buku teks utama saja. Buku suplemen ini berfungsi untuk memperdalam pengetahuan siswa dengan memberikan kebutuhan visual yang sangat kuat dalam memahami materi yang ada dalam buku suplemen.

Penggunaan teknologi dalam pendidikan sebagai upaya dalam menjawab tantangan revolusi industri 4.0 bercirikan pendidikan lebih memanfaatkan teknologi dalam pembelajaran dirasa sangat perlu untuk dikembangkan lebih lanjut. Sehingga peran teknologi AR sebagai cabang lain dari teknologi digital computer vision adalah salah satu inovasi yang dapat diaplikasikan dan dikombinasikan bersama dengan buku suplemen (Hidayat 2014). Buku ini dilengkapi dengan kajian gambar yang sudah di input marker sebagai penerjemah teknologi AR dalam memvisualisasikannya menjadi objek maupun animasi 3 dimensi yang dilengkapi juga dengan penjelasan materi dalam bentuk audio secara real time. Teknologi AR dapat memberikan beberapa pengalaman sensorik yang dapat memperkuat elemen fisik, memfasilitasi baik simultan dan kolaborasi tatap muka. Maka dalam Pendidikan, media AR dapat memberikan sebuah visualisasi yang dapat memfasilitasi peningkatan belajar siswa (Kitchenham, 2011).

Teknologi AR ini dapat diaplikasikan dalam dunia pendidikan oleh guru sebagai upaya untuk meningkatkan kualitas pembelajaran dalam kelas, karena AR ini sebagai wujud bentuk 
visualisasi virtual yang bersifat tampilannya lebih terasa nyata dalam memanipulasi objek. Hal ini membuat teknologi AR dapat digunakan sebagai fasilitator untuk membantu interaksi penggunanya dalam memahami dunia yang nyata (Suharso, 2011). Berdasarkan permasalahan diatas, pengembang berupaya untuk mengembangkan bahan ajar berupa buku suplemen sistem pernapasan manusia berbasis teknologi augmented reality. Pengembangan bahan ajar ini untuk mata pelajaran IPA khususnya pada materi sistem pernapasan manusia yang diajarkan pada peserta didik SMP Kelas VIII. Dengan begitu, pengembangan yang dilakukan oleh peneliti berupa "Pengembangan Buku Suplemen Sistem Pernapasan Manusia Berbasis Teknologi Augmented Reality Sebagai Bahan Ajar Siswa SMP Kelas VIII”.

\section{Metode}

Metode penelitian dan pengembangan ini yaitu deskriptif kualitatif. Metode deskriptif kualitatif merupakan metode pendekatan yang menggunakan studi literatur.

\section{Hasil dan Pembahasan}

Kegiatan pembelajaran yang berlangsung di dalam kelas, secara keseluruhan belum seutuhnya terlaksana dengan baik sesuai dengan tuntutan Kurikulum 2013. Hal ini dikarenakan proses pembelajaran yang masih terpusat pada guru dengan satu penggunaan buku serta media yang diterapkan dalam pembelajaran didalam maupun diluar kelas masih tergolong sangat minim. Kondisi semacam itu yang memungkinkan akan membuat siswa merasa jenuh dan tidak bisa merasakan kenyamanan saat mempelajari sebuah materi dengan baik.

Hasil saran dan masukkan yang diberikan oleh guru IPA di SMPN 21 Kota Malang, dibutuhkan bahan ajar penunjang atau pendukung pada materi sistem pernapasan manusia yang dapat memfasilitasi kegiatan belajar mandiri siswa menjadi aktif dan dapat menyatupadukan sebuah konsep menjadi satu kesatuan yang utuh. Sumber belajar yang digunakan selama ini hanya terbatas pada power point dan buku paket serta tugas dari guru yang dikerjakan dengan sumber belajar yang diakses melalui internet. Kegiatan proses pembelajaran yang berlangsung seperti itu akan menyebabkan penguasaan konsep siswa hanya menjadi sebuah hafalan saja dan pembelajaran tidak lagi bermakna. Selain itu juga terdapat materi-materi pada pembelajaran IPA yang tujuan pembelajarannya terlalu banyak, namun jumlah mata pelajaran yang tersedia tidak mencukupi untuk menyelesaikan keseluruhan dari tujuan pembelajaran tersebut, sehingga materi pokok bahasan tidak sepenuhnya dapat tersampaikan dengan baik dan maksimal.

Kegiatan pembelajaran yang menarik dapat ditunjang dengan adanya fasilitas yang mencukupi dan media pembelajaran yang melibatkan peran teknologi di dalamnya. Dengan penggunaan teknologi tersebut memungkinkan kegiatan pembelajaran berlangsung tidak terbatas ruang dan waktu. Maka dari itu perlu peran dari para teknolog pendidikan dalam memfasilitasi proses pembelajaran dengan menyediakan sumber belajar yang berbasis teknologi yang representatif yang dapat diulang-ulang setiap saat ketika akan dibutuhkan, yaitu dengan adanya bahan ajar berupa buku suplemen berbasis teknologi augmented reality. Mengenai penggunaan dan pengadaan buku suplemen ini sangatlah dianjurkan, hal ini sesuai dengan (Peraturan Pendidikan Nasional Republik Indonesia Nomor 2 tahun 2008 pasal 6 ayat 2 dan 3, 2008) yang menyatakan bahwa "Selain buku teks, pendidik juga dapat mengaplikasikan buku panduan, buku referensi penunjang dalam kegiatan proses pembelajaran. Buku tersebut berguna dalam menambah informasi dan pengetahuan peserta 
didik. Pendidik juga dapat merekomendasikan kepada peserta didik untuk mencari dan membaca buku penunjang dan buku referensi lainnya".

Melalui buku suplemen, peserta didik dapat menambah dan meningkatkan penguasaan iptek, keterampilan serta dapat membentuk kepribadian (Kurniasari, 2014). Buku jenis ini sangat dibutuhkan dalam pembelajaran karena dapat menambah pengetahuan siswa, karena dalam proses pembelajaran sangat dibutuhkan banyak sumber supaya pengetahuan peserta didik dapat berkembang dalam segala aspek, baik aspek kognitif maupun juga pengaplikasianyya dalam kehdupan sehari-hari. Dalam hal ini AR sebagai suplemen yang digunakan untuk menambahkan dan memperkuat media pembelajaran yang sudah ada serta dapat membantu peran guru dalam meningkatkan proses pembelajaran siswa dalam kelas.

Hasil dari penelitian dan pengembangan yang telah dilakukan menghasilkan produk bahan cetak dan aplikasi. Bahan cetak berupa buku suplemen sistem pernapasan manusia berbasis teknologi augmented reality sebagai bahan ajar siswa SMP kelas VIII. Aplikasi yang dihasilkan berupa aplikasi augmented reality yang bernama respiratory. Produk bahan cetak ini berukuran B5 $(17,6 \mathrm{~cm} \times 25 \mathrm{~cm})$ yang menggunakan kertas paper art. Secara umum, susunan buku suplemen terdiri dari 2 komponen, yaitu komponen utama dan komponen pendukung. Komponen utama dari buku suplemen meliputi tujuan pembelajaran, materi sistem pernapasan manusia beserta gambar yang relevan dengan materinya. Sedangkan untuk komponen pendukung buku suplemen terdiri dari cover, kata pengantar, daftar isi, petunjuk penggunaan buku, daftar pustaka, dan biografi penulis. Produk aplikasinya memanfaatkan peran teknologi augmented reality yang telah dikembangkan oleh pengembang. Pada aplikasi $A R$ yang dikembangkan berukuran $113 \mathrm{Mb}$ yang terdapat 3 menu pada tampilan awal aplikasi ini, yaitu Play, Quiz, dan keluar. Pada bagian menu Play, tampilan akan langsung dialihkan pada bagian scanner kamera belakang handphone untuk memindai objek yang bermarker yang dapat memvisualisasikan gambar dalam buku suplemen berwujud objek maupun animasi 3 dimensi serta dilengkapi dengan audio isi materi, selain itu juga terdapat 1 tombol kembali untuk menuju ke tampilan halaman utama. Bagian menu Quiz, akan dialihkan pada tampilan soal pilihan ganda sejumlah 10 soal yang masing-masing soal terdapat 4 opsi jawaban yang bisa di akses/dipilih oleh user. Pada akhir Quiz, akan ditampilkan perolehan skor akhir dan tombol kembali untuk menuju ke tampilan halaman utama aplikasi $A R$. Terakhir terdapat menu keluar untuk mengakhiri dan menutup aplikasi $A R$.

Aktivitas kegiatan pembelajaran dalam buku ini terpusat pada kegiatan pemindaian objek gambar yang ber marker $A R$ yang berisikan materi dalam bentuk audio, gambar 3D, maupun animasi. Selain melakukan kegiatan pemindaian gambar, siswa juga akan diberikan kegiatan menjawab sebuah pertanyaan sebagai feedback setelah memahami dari materi yang dipelajari untuk bisa diulas dan dituliskan kembali. Penyusunan materi dalam buku suplemen ini menyesuaikan dengan kebutuhan siswa dan selaras dengan buku paket siswa SMP kelas VIII.

\section{Simpulan}

\section{Kesimpulan}

Penggunaan bahan ajar berupa buku suplemen berbasis teknologi augmented reality dapat menciptakan kegiatan pembelajaran menjadi lebih terpusat pada kegiatan siswa 
mencari tahu informasi baru dan mampu mengkonstruknya kembali menjadi pengetahuan yang utuh. Dengan demikian kemampuan kognitif dan psikomotor peserta didik dapat meningkat.

\section{Saran}

Pengembangan buku suplemen yang layak dan valid dapat diaplikasikan untuk menjadi buku pendamping siswa dalam melakukan kegiatan pembelajaran di dalam maupun di luar kelas selain itu perlu adanya pengembangan bahan ajar untuk mata pelajaran IPA pada materi lain yang sifatnya masih abstrak.

\section{Daftar Rujukan}

Anjarsari. (2013). Pengembangan Pembelajaran IPA Terpadu. Yogyakarta: FMIPA.

Arifudin. (2011). Pengaruh Penggunaan Buku Penunjang

Daryanto. (2013). Inovasi Pembelajaran Efektif. Bandung: Yrma Widya.

Depdiknas. (2009). Panduan Pengembangan Pembelajaran IPA. Jakarta: Pusat Kurikulum Balitbang Depdiknas.Hewitt, P. G. (2007). Conceptual Integrated Science. San Fransisco:Pearson Addison Weasley.

Hidayat, D. W. (2014). Pengembangan Suplemen Augmented Reality Video Pada Buku Pelajaran Pendidikan Kewarganegaraan Untuk Pembelajaran Kelas 8 SMPMuhammadiyah 4 Singosari Malang.

Kitchenham, A. (2011).Models for Interdisciplinary Mobile Learning: Delivering Information to Students., United States: IGI Global.

Kumalasari.(2011).Pembelajaran Kontekstual. Bandung: Refika Aditama

Kurniasari, D, A. (2014).. Pengembangan Buku Suplemen IPA Terpadu Dengan Tema Pendengaran Kelas VIII., Unnes Science Education Journal 3 (2), 463.

Kurniasih, I., \& Sani, B. (2014). Implementasi Kurikulum 2013 Konsep dan Penerapan. Kementrian Pendidikan Dan Kebudayaan, 1-162.

Salinan lampiran Peraturan Menteri Pendidikan dan Kebudayaan Republik Indonesia Nomor 65 Tahnun 2013 Tentang Standar Proses Pendidikan Dasar dan Menengah, 2013

Sudjana, N. (2013). Dasar-Dasar Proses Belajar Mengajar. Bandung: Sinar Baru Algensindo.

Suharso, A. (2011). Model Pembelajaran Interaktif Bangun Ruang 3d Berbasis Augmented Reality. Majalah IImiah SOLUSI.

Sukarni, Putu. (2014). Pengembangan Buku Ajar Pendidikan Ipa Kelas IV Semester I Sd No. 4 Kaliuntu Dengan Model Dick And Carey. Bali: Jurnal Pendidikan Indonesia. 